\title{
“Sex doesn't dominate my life at all, really. I think painting does" (David Hockney): the emergence of the queer artist biopic.
} DAVID BOVEY, University of Westminster

\begin{abstract}
In the classic tradition of artist biography there has grown up a number of myths and tropes that have encouraged a pre-ordained pattern for the portrayal of an artistic life, whether literary or cinematic. Within the sub-genre of the artist biopic must now be added the category of queer artist as already distinct tropes have emerged in this relatively new field.
\end{abstract}

Where discussion of Michelangelo's sexuality was deliberately avoided in The Agony and the Ecstasy (1965), within ten years there was a sexually explicit exploration of the gay lifestyle in 1960's London in A Bigger Splash (1974). This openness and an aggressive style continued in subsequent British artist biopics though not without provoking censorship challenges and some outspoken critiques in the media. To make the filmic representations acceptable to cinema audiences, and to convey the feel of the artist's paintings, the directors used very innovative techniques to present their story. The auteurs behind these films, such as Derek Jarman, saw them as distinctly political in intent. Overall the queer artist biopic has shown more interest in exploring the private sex life of the artist than in the creation of his artistic output, but through such controversial content the artist biopic finds its place within the development of both a gay and a queer cinema.

\section{KEYWORDS}

Artist/Bacon, Francis/ Biopics/Caravaggio/Dalí, Salvador/ Gay/Hazan, Jack/ Hockney, David/Jarman, Derek/Maybury, John /Michelangelo/Queer/Warhol, Andy/ Wojnarowicz, David

\section{Introduction}

The biography of the artist has a long written tradition since Giorgio Vasari published his Lives of the Most Excellent Painters, Sculptors and Architects in 1550. Within this literary genre there grew up a pattern of myths and clichés, which in turn also became staples of the cinematic artist biopic ${ }^{\mathrm{i}}$. Gaertner (1970: 27-28) has identified that around the dominant myth of the Bohemian artist there lies the equally potent display of the mad artist or mad genius; the sick artist, whether from illness, disease, drugs or alcohol; the decadent artist and the artist who dies young. What is to be explored in this article is the more recent emergence of the queer artist. While academics have generally resisted defining 'queer' too precisely for fear of the term losing its powerful inclusivity (Stacey, 2007:1), here, 'queer' is used as an umbrella term for the wide range of sexual identities that exist alongside the heterosexual which has traditionally been taken as normative. In this sense 'queer' is more inclusive than earlier terminologies and becomes a short-hand for the coverage of, among others, lesbian, gay, transsexual, bisexual, cross-dressing and transgender associations 
(Giffney, 2009: 2). These may be very dissimilar categories but are underwritten by a mutual engagement with non-normative sexual practices or identities (Lagose, 1996: 111). This grouping implies a positive, even aggressive, 'I am in your face' attitude towards promoting the legitimacy of such marginalised categories, drawing attention to the differences from the hegemonic (hetero) sexual norm rather than trying to minimise them. However, for reasons of space, examples will be taken and arguments pursued primarily in relation to the representation of the gay male artist, providing a foregrounding of activities at the gay position on a queer spectrum. ${ }^{\text {ii }}$

From the appearance of The Agony and the Ecstasy (USA/Italy, Carol Reed, 1965), about Michelangelo, of the many films based on the lives of homosexual artists this article will focus upon A Bigger Splash (UK, Jack Hazan, 1974), about David Hockney; Caravaggio (UK, Derek Jarman, 1986) and Caravaggio (Italy, France/Germany/Spain, Angelo Longoni, 2007); Postcards From America (UK/USA, Steve McLean, 1994), about David Wojnarowicz; Love is the Devil (UK/ France/ Japan, John Maybury, 1998), about Francis Bacon; Dalí (Spain/Bulgaria/Italy, Antoni Ribas, 1991) and also Little Ashes (UK, Paul Morrison, 2008), about Salvador Dalí; and three films featuring Andy Warhol, I Shot Andy Warhol (UK/USA, Mary Harron, 1995), Basquiat (USA, Julian Schnabel, 1996), and Factory Girl (USA, George Hickenlooper, 2006).

Already distinct tropes have begun to emerge in this relatively new field, in particular the downward trajectory and intense suffering and victimisation more usually associated with the female biopic. Bingham (2010: 10, 213-220) in his recent history of the biopic asserts that male and female biopics are distinct genres and divides his book accordingly. While for the male, the Great Man or the Wild Genius can succeed against all odds to make his mark in his chosen field and improve the quality of society, for the female any public success is only gained at a very high price after experiencing suffering, victimisation and failure. However, the queer artist has tended to follow a path nearer to the female stereotype than to the Great Man scenario, in that his/her eventual success comes at a high emotional price. ${ }^{\text {iii }}$ Nonetheless it is a less steep downward trajectory compared to the female in that he remains sane and does not have to be locked away. Bingham (2010: 222) suggests, "The dominant film institutions - and male directors - think they are being sympathetic to women by showing the process by which means women are washed out as human beings and wash themselves out".

This attitude also pervades the queer subject, for example, during A Bigger Splash (Jack Hazan, 1974), Hockney spirals into a deeper and deeper depression over the loss of his lover, Peter Schlesinger. After suffering a creative block, his recovery in putting together his recent work for a successful gallery exhibition in New York, is overshadowed by the ending, where he is so disillusioned that he disappears without contacting his friends in New York. In Little Ashes (Paul Morrison, 2008), Dalí runs off to Paris to escape his feelings towards Federico García Lorca. This leads to the monetary success and fame he craved, but his reunion with Lorca eight years later makes plain that such trappings have not really compensated for his loss of Lorca and that his wife Gala only partially appeases his sexual desires. The unsuitability of such a liaison, made hopeless by Dali's phobia of being touched, is mirrored in the intense homophobia exhibited on several occasions by the third famous persona in the student 
triumvirate, filmmaker Luis Buñuel, including his serious attack on a man cruising in the park at night.

\section{The Gay Artist and 'Rough Trade'}

The development of specific tropes, however, does not imply a standardised and predictable end product, owing to various influences that will be considered here. The interpretation of these tropes can be very varied allowing a queer artist's story to be told as it were in a queer voice. To take one very common thread: the rite of the young impecunious gay artist experiencing a period of promiscuous rent-boy activity before reaching sexual maturity has been handled in very contrasting ways. This can be shown by comparing the treatment of sexual hustling by a teenage Caravaggio in Renaissance Italy in Jarman's 1986 film version against that of the twentieth-century American artist David Wojnarowicz in Postcards From America (Steve McLean, 1994). David's rape by the driver of a pick-up truck giving him a lift in the desert is the lowest point within the downward trajectory of the film, and it has a horrifying inevitability. David's first words to the driver -"How far are you going?" - echo with double entendre. Wojnarowicz has already suffered nearly two decades of abuse from both his father and strangers. The audience knows that this new episode will also end in disaster, especially if they have seen any of those Hollywood movies where it is always dangerous to accept motor rides involving complete strangers out in the middle of nowhere, such as The Hitcher (Robert Harmon, 1986) ${ }^{\mathrm{iv}}$. The Postcards director, Steve McLean, implies it is a rite of passage, a major step on Wojnarowicz's way of realising that he must alter his life style to ensure his survival. It is a very chilling rather than celebratory sequence.

The rape is depicted realistically, repulsively even, as the fear and violence are emphasised by the careful use of darkness and shadow and a lack of colour. The truck curtains are a pale brown: the driver's shirt is dark blue; David's leather jacket is black; the truck is black; the only light comes from the dimmed headlights of the parked vehicle. During the assault there is a reliance on a hand-held camera continuously on the move, providing close-ups to show the claustrophobic nature of the event. The combination of muted colour and the disorientation of movement linked with close-ups imposes a degree of objectivity to what is happening on the screen, enabling the sequence to be bearable to watch at all. McLean also invokes a worrying ambiguity to the episode, as to whether David has provoked and/or enjoyed the encounter. By the cutting of the soundtrack and only partial visibility of David's head his cries can be heard as a mixture of both pleasure and pain. Similarly, in the sequence that follows David walks fully clothed into a lake at dawn. This is because he is obviously hot and dirty after his night adventure, but as he is fully clothed it suggests more than a simple need to bathe, it also becomes a form of holy cleansing and a baptism, a part of his trying to expunge a distressing episode from his memory and start life refreshed in the hope of a better life to come.

There is a great contrast between Wojnarowicz's experience and Jarman's treatment of Caravaggio's early life as a hustler. ${ }^{v}$ An elderly man approaches the teenage Caravaggio who is painting in a street in Rome. There is gentle humour at work here as a completed version of Still Life with a Basket of Fruit (c1599) lies casually displayed on the steps nearby. The two males have a conversation full of doubleentendres and amusing knowing looks which leads up to Caravaggio showing his split 
trousers and the client accepting Caravaggio's offer of a sexual encounter. Caravaggio is being watched over by a pimp who nods his agreement to the deal. We next see the couple in Caravaggio's room post-coition. They are engaged in very physical horseplay which ends with Caravaggio drawing a knife on the elderly client and taking his wallet before the man runs out of the room hastily in fright. Caravaggio flops onto his bed and, highly satisfied with himself, contemplates his easily earned gains.

This basically sordid transaction is transformed by Jarman's mise-en-scene. The exterior street is an intoxicating mixture of vibrant colour and sounds. It is dappled in the warm sunny glow of orange and pastel green, brightly lit, and accompanied by sounds recorded in a modern Italian street. ${ }^{\text {vi }}$ As the scene cuts to the interior of Caravaggio's lodgings a bright and loud folk dance is on the soundtrack and Caravaggio and his client play a game of chase in a circle. Caravaggio passes a bottle of wine from hand to hand in time to the music which grows faster and faster. The use of a revolving camera varying the depth of focus as well as offering shots in unstable angles makes the encounter appear as a merry dance. The mood abruptly changes when the music finishes. Caravaggio draws a knife from under his pillow but his menace is muted by his comic dialogue. When left on his own he gradually transforms himself into a pose reminiscent of a mixture of Caravaggio's Bacchus (1595) and Boy With a Basket of Fruit (1593) via knowingly donning a crown of laurel and picking up a basket of fruit (Jarman, 1986: 21). At the same time, on the soundtrack the older Caravaggio intones his considered view of his lifestyle at this early point in his life, so giving credence that the young reprobate just shown is capable of being transformed into the serious painter that is yet to come. ${ }^{\text {vii }}$

Via these diversions Jarman succeeds in turning Caravaggio's offering himself for rough trade into part of a sentimental education rather than a matter of crude physical abuse such as that suffered by the similarly aged David Wojnarowicz. The edgy filtering of sexual experience also owes a debt to the way criminal and writer Jean Genet projected his life experiences (Gardner, 1996; 39-40). All is kept light and joyous despite the potentially licentious content. ${ }^{\text {viii }}$ There is a safety in the studio sets rather than the social realism of Postcards From America. The pimp may carry a knife but is using it to cut juicy fruit, presaging the discharge of bodily fluids to come. The client is elderly and therefore easily controlled. He is also made a figure of fun by being shown with his trousers down around his ankles and befuddled by wine. The jaunty soundtrack music is uplifting and deliberately upbeat. The rapid movements of the revolving camera avoids the potential for a salacious voyeuristic scene as the spectator fails to identify with either Caravaggio's or the client's point of view. Caravaggio's body is not held within the frame which reduces the potential for it to be seen as an erotic spectacle, and also avoids the fetishisation of Caravaggio as a piece of 'rough trade'. The slight frisson of danger that is allowed is quickly defused. Caravaggio has a knife hidden under his pillow. The mere showing of it is enough to extract the client's wallet without further ado. The fun continues. Caravaggio shouts out, firstly in Italian, then: "In plain English, mate, I'm an art object and very, very expensive". At this stage in his life Caravaggio's street-wise tough masculinity is straight identified (Richardson, 2005: 42-43). The sale of his body is a safe fantasy that is essential to forming what Jarman has described, based on his reading of the artist's paintings, as "the most homosexual of painters" as an adult. 
Another variation on this trope of hustling continues with the adult queer artist chasing the classic gay cliché of the attraction of the gay artist to 'rough trade'. ${ }^{\text {ix }}$ This is depicted most powerfully in Love is the Devil (John Maybury, 1998) and more equivocally in Jarman's Caravaggio (1986). In the former the working class George Dyer from London's East End becomes the lover and muse to Francis Bacon and it is their relationship, rather than Bacon's painting, which is at the heart of the film and which prompted John Maybury to accept its directorship (Weston, 1998: 38). In a pivotal sequence, when the two men prepare for a sadomasochistic sexual encounter, they proceed as if participating in an ancient ritual. It is enacted in a severely formal style. Each item of clothing is removed in strict order and placed meticulously in its designated place in the bedroom, so each detail is eroticised (Kalin, 1996: 62). At the same time the procedure exhibits the accoutrements of the well-dressed British man circa 1967.They appear to be concentrating on getting this procedure just right. The pair are completely silent but Maybury magnifies the sound of each of their movements so the rustle of clothes or the jingle of cuff-links begin to form a kind of solemn musical accompaniment while at the same time providing a Brechtian distancing effect. The audience is continually reminded that they are merely watching play acting which helps make the depiction of a potentially repellant scene bearable. This cacophony of preparation culminates in George wrapping his belt slowly, taut around his hand, snapping leather against leather. The scene ends with Bacon kneeling by the bed as Dyer walks towards his bare back with a lit cigarette, which crackles. Finally Dyer breaks the silence, with the powerfully moving word "Sorry" as the image fades to black (Jones, 1998: 79).

Jarman, however, depicts an unfulfilled passion, which while based initially on a rough trade attraction is immersed in ambiguity. Caravaggio never achieves a gay romance with the criminal Ranuccio Thomasoni. ${ }^{\mathrm{x}}$ The desire between the painter and his model is plainly there, but circumstances see it ended prematurely. Nevertheless, Ranuccio's stabbing of Caravaggio can be seen as an act equating to a sexual pleasure, while the feeding by mouth of gold coins between the artist and Ranuccio is also sexually charged. The fluidity of the combinations of sexual boundaries between the three leading characters provide a multiplicity of queer readings. The relationship collapses in violence, as the two men's sexual roles appear to change. As the hitherto 'straight' Ranuccio confesses he has murdered his former mistress Lena out of love for Caravaggio, so Caravaggio slits Ranuccio's throat for foreclosing on his hitherto unacknowledged adult heterosexual attraction to, and artistic inspiration found in, Lena.

\section{Production Processes and the Representation of the Queer Artist}

In the development of their tropes nearly all the queer artist biopics only deal with a partial life of the artist, not a 'cradle to grave' structuring. The focus on short time periods promotes a concentration on the artist's personal relationships amid a search for a specific catalyst to provide a key to the flowering of the artist's creative genius at a particular time. The only film taking the whole life, Caravaggio (Angelo Longoni, 2007), was made with a long version for television screening as well as theatrical distribution in mind. The rest of the films choose to explore their chosen themes in depth. For example, The Agony and the Ecstasy (Carol Reed, 1965) was only interested in the period 1508-1512 when Michelangelo was sparring with Pope Julius II over the decoration of the ceiling of the Sistine Chapel. In A Bigger Splash 
the breakup of Hockney's relationship with Peter Schlesinger and the consequent fallout covers three years from 1969. In Love is the Devil we can follow Bacon's relationship with George Dyer over eight years. Postcards from America only shows David Wojnarowicz from the age of ten to about twenty. It is a palimpsest equivalent to a set of postcard notes sent over the ten year period as it is based on Wojnarowicz's series of impressionistic short essays, including that with the film title, published in Close to the Knives (1992). While Jarman's Caravaggio shows him from a boy to his death, the artist's life is incomplete and patchy, only selecting one or two moments of particular importance to either his artistic or emotional development, as it concentrates on his period in Rome and omits his Maltese adventures entirely. Morrison's Little Ashes for two-thirds of its running time focuses on the relationship of Dalí, Lorca and Buñuel at University in Madrid in 1922-1925. Even the three Warhol films each take a different timeframe to look at his fame, with Factory Girl (George Hickenlooper, 2006) showing his attraction to Edie Sedgwick in 1965-1966, at the time he was switching from painting to filmmaking. I Shot Andy Warhol (Mary Harron, 1995) leads up to Valerie Solanus's shooting in 1968, and Basquiat (Julian Schnabel, 2006) deals with his art and friendships after Warhol's recovery from his serious injuries.

Within the queer artist biopic there is a generally aggressive attitude around a frank and even 'in your face' sexuality. Only in the two European biopics, Caravaggio (2007) and Dali (1991), is the element of homosexuality very marginal or equivocal. In the rest of these films homosexuality is dealt with as a central issue and it is accepted as an everyday element within the section of society portrayed. This was not there, however, in the beginning in 1965 in The Agony and the Ecstasy, where there is a careful avoidance of the question of Michelangelo's sexual preference. This is not surprising considering the film was a huge blockbuster with a budget of ten million dollars and a cast of thousands and such high investment meant the studio wanted to play safe and avoid any controversial aspects of Michelangelo's life. Carol Reed attempts to bring in some love interest with Contessina di Medici (Diane Cilento) nursing Michelangelo (Charlton Heston) when he has a physical breakdown but the script even leaves this uncertain. It is as if the unspoken suggestion of his homosexuality is very much present, making the attempt at tender romance bloodless. There is a brief reference to the situation at Michelangelo's sickbed. When asked by the Contessina why he refuses to have an affair with her, his eyes cast around the studio and alight on the drawing of a naked man and Michelangelo says, "It's not that either". His disinterest in the opposite sex is laid firmly at his being wedded to his art. That mistress demands all his time. The script says "Maybe God has crippled me, with a purpose, as he does often...He gave me the power to create. I'm filled with love, but of a different kind", which is re-emphasised at the end of the film when the Contessina's reaction on viewing the completed ceiling is, "There's more love here than could ever exist between man and woman". ${ }^{\mathrm{i}}$

By 1974, with A Bigger Splash there explodes a sexually explicit exploration of the gay lifestyle in 1960's London. This is given enhanced shock appeal because at the time it was thought to be very much a cinema verité record documenting David Hockney and his entourage, whereas in fact it was scripted and carefully edited to tell a semi-fictional story (Bovey 2011: 375, 377-378). In retrospect it was a landmark film in gay cinema, if only because, as Collinson (1975: 37), writing in the gay magazine Quorum, considered that despite its pretentiousness "it makes no attempt to 
explain or to depreciate or defend its characters' gayness: this acceptance of gayness is so rare in films and plays".

This openness and a direct style were to become a hallmark of the subsequent British films - Caravaggio, Postcards from America and Love is the Devil. These are all low budget independent art-house films where greater risks can be taken, or indeed are expected. However, even for these money was not easy to raise and production was difficult (Bovey, 2010: 2). For example, Jack Hazan mortgaged his house as well as pursuing a full-time job while making A Bigger Splash. He had to fit filming around both his own work commitments and what suited the Hockney entourage. He aimed for two or three days a week filming, but Hockney soon got fed-up with the invasion of his privacy. It was only after Hazan found him special lights so he could work all night while preparing his paintings for show right up to the last minute, that he felt that in return he owed Hazan special access to complete filming, especially the right to film him actually painting (Bovey, 2011: 378).

For others access to the artist's work was also difficult. For example, the Bacon estate would not co-operate with John Maybury making Love is the Devil, and refused all permissions to reproduce Bacon's works. It also went further and insisted on prohibiting the use of any of Bacon's interviews, so Maybury had to make up his own style of Bacon's speech. He was so successful that it was thought to be real quotes, even by Bacon's closest friends (Bovey, 2010: 5). Such difficulties proved to be artistically stimulating as the directors were forced to refine their approach to the biopic. ${ }^{\text {xii }}$ For other films it helped to have a sympathetic producer. For example Christine Vachon (1998: 127) recognised the special dangers and possibilities of working in the low-budget independent sector, producing both Postcards from America and I Shot Andy Warhol. She made use of Strand Releasing, a supportive specialist distributor, to make the most of the market via an intense public relations exercise on the gay press, and a commercial advertising campaign based on the basic appeal level of a bare-chested James Lyons on posters (Vachon, 1998: 292-293). There was no attempt to tie the film in with the other side of Wojnarowicz's activities, his campaigning against public and governmental indifference to AIDS or the fact that his main work was by its locational specificity and ephemeral nature, displayed outside the confines of an art gallery (Cooper, 1986: 17).

Necessity became the mother of invention when budgets were constricted and access to sources denied. With a small budget from Channel 4, Derek Jarman was forced to make Caravaggio in an old warehouse cheaply converted into the shoddy Limehouse Studios. Rather than going location shooting he used sound recordings made at the site of Caravaggio's wanderings in Italy to introduce a Mediterranean ambiance to his enclosed studio sets. Even these were pared down to the bone, as Cardinal de Monte's art gallery is represented by a single bust on a plinth, the rest of his visible objects being under dustcovers (Peake, 1999: 351). To simulate the sheen of a marble palace floor the studio floor was soaked with water that reflected the studio lights. The paintings were reproduced as tableaux, permitting Jarman to add-in his own idiosyncratic details. Indeed, not only Caravaggio's work is invoked, for example, the scene of the critic Giovanni Baglione typing in his bath is a pastiche of David's The Death of Marat. The many anachronisms in the film emphasise Jarman's disdain for the Hollywood blockbuster tradition of exact replication of accurate detail. 
For John Maybury, the denial of reproduction of either Bacon's work or interviews led him to find a way to invoke the spirit of Bacon's work without infringing any copyright. In association with his regular cameraman John Mathieson and production designer Alan Macdonald, he was able to build on his experience of working on pop promos and cutting edge video techniques, to create within the camera, as well as a few sequences of CGI, how Bacon saw the world through his paintings. There are many shots filmed using special lenses that deliberately distort the character's features, making them into grotesques. This effect is doubly effective when accompanied by shooting the scenes from low down and pointing the camera upwards, just as in the trademark style of Bacon's drinking companion, the photographer John Deakin. Shooting through glass was also used to create distortion, and a restricted colour palette reflected the limited colour range used in Bacon's paintings (Willis, 1998: 48-51). This meant particular use of old-fashioned techniques such as double exposure within the camera, the use of a boroscope and a variety of coloured gels. Sets were largely lit by bare light bulbs, echoing their use in Bacon's paintings and in his studio. Maybury did consider it important to shoot on location in certain instances to get the correct atmosphere. For example, he used the St. John restaurant in the East-End of London, used by the current YBAs(Young British Artists), rather than Wheeler's regularly frequented by the Bacon ensemble. He went further than this by calling on favours owed from the YBAs to use these artists as extras within crucial scenes, which emphasised the continuity of the drinking culture and the artists debts to Bacon (Del Re, 1998: 77).

For McLean, directing Postcards From America, his mixing of time periods, resulting in a very complex narrative structure, was made simpler for the audience by using three actors to play David Wojnarowicz, with Olmo Tighe as a child, his brother Michael as a teenager, and James Lyons in his early 20s. Each period of David's life is also represented differently. His childhood features sparse sets, usually set up in the round surrounded by darkness, at once moody and frightening, accompanied by unsettling rumbling noise, equating to the anger about to spill out of his father. For the teenage years the view is often surreal and alternative scenarios illustrated, while the young adult is enmeshed in a hot desert environment where it is an effort to even speak.

\section{The Queer Artist Biopic and the Development of Queer Culture}

The arrival of the queer artist biopic needs to be seen within the wider context of the development of a queer cinema and how its depiction of minority sexual and gender categories challenges both general public tolerances and the current state of censorship. A Bigger Splash was exceptional in appearing at a time when mainstream studio fare was still only using stereotypical gay characters. The British independent sector was tuned into an increasingly realistic depiction of gay life at least for a niche audience. Jarman's Sebastiane (1976) was able to go further on the back of A Bigger Splash's censorship battles, but had to retreat to an historical Roman time period. However, this film was quickly followed by Ron Peck's Nighthawks (1978), which did show the contemporary gay life of a London schoolteacher, including the frequenting of West End clubs such as Heaven. The appearance of a relatively large number of films with a queer theme in the 1990s, particularly in the United States, can be seen as part of what B. Ruby Rich ( 1992: 32) christened the 'New Queer Cinema'. Whereas more classical gay and lesbian films had used conventional narrative 
structures to present 'positive images', this was an outpouring of queer independent films that Benshoff, (2006: 220) has described as being "increasingly edgy, angry, and theoretically rigorous. These works were unapologetic in their frank look at sexuality and combined stylistic elements drawn from AIDS activist videos, avantgarde cinemas, and even Hollywood films". Love is the Devil and Postcards From America show the characteristics of this categorisation. However, by the turn of the century Rich (2000: 22) saw such an outpouring as becoming "a moment rather than a movement", with new material, as in Factory Girl or Little Ashes, itself becoming both clichéd and also absorbed without adverse comment into the mainstream.

Criticism of the tendency towards frankness in the queer artist biopic came not only from more conservative sections of society generally, but also from some in artistic circles that one might have supposed would be more in sympathy to the recognition of revised definitions of gender and sexuality. For example, on the release of Love is the Devil John Maybury has commented that "I was shocked by the response I got from the cultural establishment" (quoted in Buck, 1998: 6). "They've asked me to remove facts because they were offended" (quoted in Macnab, 1997: 19). Maybury was particularly incensed at the intervention of Lord Gowrie as Chairman of the Arts Council who suggested to the Board of the Council that they should not fund the film (Davies, 1997). Maybury found that he "came up against resistance from the art establishment in this country... all basically said 'This film is not going to be made'. It was extraordinary to have these people ganging up against something which at the time was such a small thing" (quoted in Kalin, 1998: 61).

Looking at the long term, Richards (1997: 18) has traced a British cultural revolution back to the affluence, full employment and materialism of the 1950s and 1960s, so that gradually "the rebel and the deviant became heroes, the self was exalted, spontaneity was encouraged and rules, restrictions, conventions and traditions in both life and art were ditched. The old structure, old values and old certainties (notably the doctrine of respectability) were increasingly derided and rejected...Violence, profanity and sexuality, hitherto rigorously suppressed, became prominent both in high culture and low". In this regard, Richard Dyer (2002: 205) has pointed out how wider acceptance of gay culture and lifestyle resulted in heritage cinema being "truly hospitable to homosexual subject matter", where the historical context made it palatable to a wider audience. When depicting contemporary situations there was much less tolerance. The fact is that for much of the period dealt with in artist biopics, there existed a homosexual rather than a gay culture, as in the UK homosexual acts were illegal and imprisonable offences (Macnab, 1997: 20). It was the Sexual Offences Act 1967 which decriminalised homosexual acts in private between two men, both of whom had to have attained the age of twenty-one, but only in England and Wales. ${ }^{\text {xiii }}$

A Bigger Splash was originally given the honour of opening the 1973 London Film Festival after receiving favourable reviews at its premiere in the Critics Week at the Cannes Film Festival. However, Keith Lucas, the Chair of the organisers, the British Film Institute, very publicly withdrew the invitation after viewing the film, on the grounds that it would offend the many dignitaries from London councils invited to the opening night (Ryman, 1975: 14). After much negotiation it was awarded the consolation prize of being the closing film for the Festival (Richmond, 1975: 7). The subject matter of a world renowned artist together with high art was also insufficient 
to avoid the attention of the American customs when a copy of the film was sent to the New York Film Festival. The Department of Customs and Excise denounced it as "disgusting and immoral" and at first limited it to a single showing (Webb, 1988: 144). The resulting publicity led to a sell-out and further showings were negotiated. Similar problems arose in France where the film was intended to open in Paris at the same time that the Musée Des Arts Décoratifs, Palais du Louvre was showing a Hockney retrospective. The French censors held up the film for three months and it was only the personal intervention of the Minister of Culture that gained its release (Ryman, 1975: 14). The film proved so popular that in both London and Paris it ran for several months, with the highest weekly gross of any cinema in London for the first three weeks, but with the compromise of a couple of minutes of cuts for British audiences (Hazan, 2006: Section on 'Grosses').

For Love is the Devil, the opposition of the great and the good also gave the film publicity it would otherwise never have achieved (Davies, 1997). There was also a running battle between Maybury and the well-known Evening Standard film critic Alexander Walker that became very personal. Walker's vituperation recalled the fire and brimstone orations of earlier centuries. ${ }^{\text {xiv }}$ Films on queer artists suffer from approbation conferred without the detractors necessarily having even viewed the work. They are very easily associated with an unsavoury image. Postcards from America was briefly lifted from obscurity in 2002 because of a legal action by the singer Connie Francis who objected to the use of four of her songs on the soundtrack. She described the film as "vile and "pornographic" and sued Universal Music Corporation for forty million dollars (Connie, 2002: 1).

A large part of this opprobrium is caused by the link between the representation of the queer and political activism. This is on the part of both the director and the subject of the film for say Jarman and Maybury. For Steve McLean's Postcards it is more the subject. Both Derek Jarman and David Wojnarowicz were in the forefront of the battle for gay rights and a more supportive government response to the AIDs epidemic on their respective sides of the Atlantic. They both felt oppressed in the way society treated them and attempted to make their points very vocally, producing diaries, notebooks, works of art and interviews at a punishing rate to keep the problems in the public eye. Jarman's Caravaggio can be seen as part of the gay response to seek out the gays of the past and reincorporate them into history that had previously ignored their presence. In turn the example of the past proves relevant to the situation in the present. Both films take on a resonance because of the celebrity of director and/ or subject. While Caravaggio is a hymn to the artist as well as politics, Postcards becomes a strong political statement as it recreates the tragic life of Wojnarowicz before he is rescued from abuse and prostitution. There is no direct reference to his later maturation into a famous artist. In two kitchen scenes, when he is in his early twenties, there are a bundle of artist's paintbrushes in the sink. One of his clients sees he has an eye for artwork and gives him some very basic hints on how to view a painting hanging in his house. However, this is counterbalanced by the man's obvious impatience to take David to bed and David imagining bludgeoning the man to death with a handy statue before he leaves, despite the client's friendly disposition.

For Hockney, Bacon and Warhol the queer nature of their artistic production was unacknowledged in the art world for a long period. For Bacon and Hockney there was 
complicity on their part within this situation. As Lucie-Smith (1979: 7) suggests, Bacon's paintings hint at a homosexual context without ever being quite specific about it. It was acceptable because of its ambiguity. Even the most specific, Two Men on a Bed of 1953, can be given the benefit of the doubt as it was based on a photograph of two naked athletes by Victorian photographer Eadweard Muybridge. For Hockney, while his early works may jokily refer to homosexual stereotypes, such as Doll Boy (1960), they are never erotic, while his later mid 1960s more explicit illustrations to accompany Cafavy's poems, can shelter behind the act of merely interpreting a set text, rather than expressing his own sentiments. Cooper (1996: 2324) points out there was also the lack of an adequate language to describe such works, with critics falling back on a formal discussion of form - use of colour, historical precedents- and ignoring the issues surrounding the life of the artist. For Bacon's work this was especially problematic as so much of it was self-evidently pertaining to specific events, often depicted with violence and passion.

While the gay content of such paintings may therefore have been ignored, the filmic representations of their painter's lives have certainly not followed suit, accounting for some of the censorship battles mentioned above. Once such scenes or their painter's lifestyle are transposed to the large cinema screen shared by an audience, there is a different type of reaction to safely viewing a small, stationary image mounted on a wall or hearing the latest gossip about a personality. The gay world becomes real and can be naked, sweaty and bitchy. Butt (2005: 108) analyses art world gossip in New York to show how Warhol's 'swishiness' was unacceptable even to other successful contemporary gay artists such as Jasper Johns, who thought by such cavorting he brought disrepute to the artistic world and the status of gay artists within it in particular. ${ }^{\mathrm{xv}}$ Rather than change his persona, Warhol worked on overcoming this image by promoting himself as a modern Oscar Wilde, what Butt (2005: 13) describes as "the now familiar asexual postmodern dandy." Warhol is recognised by the public first and foremost as a style icon, and queer only as a secondary condition. There is the deliberate adoption of a "cold distant detached personality" where "Warhol deliberately creates himself as freakish, queer other" (Butt, 2005: 117-118), by the use of silver blond wigs, worn uncombed and slightly askew, mumbling and monosyllabic, so often incoherent, and exaggeration of his 'swish' features, particularly his walk and limp wrist. The three films featuring him follow this mould, showing him at periods by which he was already firmly established on the New York social as well as artistic scene, and where his artistic output had moved away from painting towards film.

As already mentioned, the three films about Warhol provide three snapshots of the artist at different artistic stages of his life. While he is not the principal subject of any of these films, his screen time is sufficient to display his character in depth and commensurate with the pivotal nature of his relationship with the principal figure. The arch media manipulator can be seen transforming himself. ${ }^{x v i}$ Seeing three different actors in the role emphasises this chameleon like ability in the original artist. All three actors reproduce the distinctive voice and walk, but otherwise indicate how his representation was always changing. Guy Pearce in Factory Girl is appropriately the most outgoing and confident as he becomes a media star alongside his 'superstar' Edie Sedgewick. Jared Harris in I Shot Andy Warhol is the most reticent and uninvolved, who pays heavily for being relatively nice to Valerie Solanus. With Basquiat, Warhol finds renewed inspiration through the young painter, returning to 
painting from filmmaking and perhaps also falling in love with the man. Alongside this rejuvenation comes a change in physical appearance, as Bockris (1998: 461) describes, "from Brooks Brothers shirts and ties to black leather jackets, sunglasses and black jeans", making him look younger and thinner, which ideally suits the physique of David Bowie playing him. ${ }^{\text {xii }}$

The casting of Bowie in itself brings another element of queerness to the film. His iconic status within pop music culture was partly built upon the ambiguity of his sexual image, both on stage in the flamboyant androgynous alter ego Ziggy Stardust, and also offstage with his open declaration of bisexuality within his heavily publicised private life. As Warhol's personal appearance changes, so too do the surroundings in which his performance is set. The 60s world of Factory Girl is a distinctly queer one. No one viewing the film can miss the transvestite, transgender and sado-masochism invoked at the Factory in its party days. The effeminate side of Warhol is projected in the juxtaposition of two sets of cross-cutting between Edie and Andy. Firstly, when they are both getting ready to go out on the town, with Edie choosing her make-up juxtaposed with Andy choosing his wig, both in front of their mirrors. Secondly, with each sitting naked in a bubble bath in their respective homes, talking on the "phone, Andy is doubly feminised by his wearing of a very unglamorous plastic hair protector. By the time Valerie Solanus shoots him in an upstairs room at the Factory, the Factory glitz has been left behind and in I Shot Andy Warhol the incident shows how far the former Bohemian catalysts of the Factory have metamorphosed into sober suited business administrators, working at their office desks. Andy himself is also dressed very soberly even if not in a suit. It is left to one of Warhol's transvestite superstars, Candy Darling, played by Stephen Dorff, to provide a clear link between the lesbian world of Valerie and the queer world that still remained on the fringes of Warhol's factory. In Basquiat, while Basquiat and Warhol do collaborate in artistic works, their interaction is largely confined to the bare painting studio, which reflects the way Warhol in real life excluded Basquiat from the Factory building for several years, to distance himself from the drug-related party years and sustain a new, more sober image with his return to painting from movie-making (Bockris, 1998: 460).

\section{Conclusion}

The Hockney quotation used in the title of this paper exposes the major contradiction within the queer artist biopic, which has shown more interest in exploring the private sex life of the artist than in the creation of his artistic output. However, when placed in its full context even Hockney had some sympathy with the filmmakers' view, considering that the director, Jack Hazan, "In the end... he emphasised things emphasising the gayness was a bit much. Sex doesn't dominate my life at all, really. I think painting does. It's just a small part. I suppose it's just the publicity - people are interested in it because of that really - to see the homosexuality which I thought as just an accepted part of people's lives" (Hockney, 1975: 9). Monk (2000: 156-157) certainly sees a wider acceptance of sexual identities within British films of the 90s, at least in those confined to the art-house circuit. Indeed, she considers it apparent to the extent that "male gayness had gained mainstream acceptance as a lifestyle (or cluster of lifestyles)". By the time Little Ashes is released in 2008, even though the revelation of a homosexual relationship between the leading historical characters is the raison d'être for the production, this aspect attracted little comment among reviewers. Interest was centred on the appearance of Robert Pattinson playing Dalí, and released 
immediately after his first huge success in part one of the Twilight Trilogy, Twilight (Catherine Hardwicke, 2008) concerning teenage vampires. John Maybury in Love is the Devil used Bacon as his mouthpiece to express the importance of a queer lifestyle to his work, when he said,

"When I went into the house of pleasure I didn't stay in the room where they celebrate acceptable modes of loving in the bourgeois style. I went into the rooms which are kept secret. And I learned and lay on their beds...I went into the rooms which are kept secret, which they consider shameful even to name. But there is no such shame for me. Because then what sort of poet and what sort of artist would I be?" (Maybury, 1998: 14-15).

A more cynical view is expressed by Alexander Walker (1997: 53) after many years as a film critic, noting “Tragic obsessions like Bacon's, which may have been the wellspring of his art, are the principal reasons why commercial cinema is hooked on art. The reputation of the artist is the licence for movie-makers to deal with sexual perversions and violence that would be harder to present in the lives of folk who are not so venerated for their talents or their market value". This means, as Dixon (1998: 33) comments, "For filmmakers the struggle in the studio remains typically psychosexual rather than technical". Although film is in this sense ultimately dependent on financial success and biography is moulded to this purpose, it is to be hoped that the increasingly casual and explicit depiction of the queer lifestyle of several artists also reflects more open attitudes to sexuality within society generally.

\section{References}

Anderson-Minshall, D. (2011) 'Nicole Kidman's transgender film shelved', The Advocate, October $9^{\text {th }} .1 \mathrm{pp}$. http://www.advocate.com/arts-entertainment/film/ 2011/10/09/nicole-kidmans-transgender-film-shelved [accessed 22/05/2012]

'Bacon sliced', The Times, 29 September. BFI Microfiche Press Cuttings Collection

Benshoff, H. M. and Griffin S. (2006) Queer Images: A History of Gay and Lesbian Film in America, Lanham, MA: Rowman and Littlefield. (Genre and Beyond: A Film Studies Series)

Bingham, D. (2010) Whose Lives are They Anyway? The Biopic as Contemporary Film Genre, New Brunswick, N.J.: Rutgers University Press

Bosquet, A. (1969) Conversations with Dalí, New York, Dutton

Bockris, V. (1998) The Life and Death of Andy Warhol, London: Fourth Estate

Bovey, D. (2010) 'Unruly, devious and queer: a critique of post-war British artists within British artist biopics', Pied-à-terre, 1, Printemps: 18-26. Also available at. www.geiab.org/GEIAB DEUX/index.php?lang=eng\&revue =showit\&rn=1\&article id=19\#begin [accessed 03/07/2012] 5pp.

Bovey, D. (2011) 'Starring David Hockney: authenticity and filmic performance in "A Bigger Splash"', Journal of British Cinema and Television, 8, 3, October: 375-391 
Buck, L. (1998) 'Putting Bacon in the pictures', Art Newspaper, 10, 84, September: 6

Butt, G. (2005) Between You and Me: Queer Disclosures in the New York Art World, 1948-1963, Durham, NC: Duke University Press

Collinson, L. (1975) 'The Collinson column', Quorum, 2,10: 35-36

'Connie Francis sues Universal Music over movie licences' (2002)

www.imdb.com/title/tt0110876/news [accessed 03/07/2012]

Cook, M. (2007) 'From gay reform to Gaydar, 1967-2006' In: Cook, M. ed. A gay history of Britain: love and sex between men since the Middle Ages, Oxford: Greenwood World Publishing, 2007 pp.179-214

Cooper, E. (1996) 'Queer spectacles' In: Horne, P and Lewis, R. eds. Outlooks: Lesbian and Gay Sexualities and Visual Cultures, London: Routledge, 1996 pp.13-27

Davies, C. G. (1997) 'Sizzling saga of Bacon and a hot potato', London Evening Standard, 02/07/1997. BFI Press Cuttings Microfiche Collection

Del Re, G. (1998) 'John Maybury: infatuation with cable tv', Flash Art (International Edition), 31, 203, Nov/Dec: 74-77

Dixon, S. (1998) 'Picture perfect: artist stereotypes in film', Art Papers, 22, 6, November/December: 32-33

Dyer, R. (1993) 'Coming out as going in: the image of the homosexual as a sad young man' In: Dyer, R., The Matter of Images: Essays on

Representation, London: Routledge, 1993 pp.73-92

Gaertner, J. A. (1970) 'Myth and pattern in the lives of artists', Art Journal, 30, 1, Fall: $27-30$

Gardner, D. (1996) 'Perverse law: Jarman as gay criminal hero' In: Lippard, C. ed., By Angels Driven:The Films of Derek Jarman, Trowbridge: Flicks Books, 1996 pp.31-64

Giffney, N. (2009) 'Introduction: the "q" word', In Giffney, N and O'Rourke, M. eds. The Ashgate Research Companion to Queer Theory, Farnham:

Ashgate., 2009 pp.1-13. (Queer Interventions)

Hazan, J. (2006) 'Interview, by Adam Roberts', included on DVD HOCK001/ VDF01198 of $A$ Bigger Splash

Hockney, D. (1975) 'I didn’t want to be a movie star’ Time Out, 11-17 April: 9 Jarman, D. (1984) Dancing Ledge; edited by Shaun Allen, London: Quartet Books 
Jarman, D. (1986) Derek Jarman's Caravaggio, photographs by Gerald Incandela, London: Thames and Hudson

Jones, K. (1998) 'Love is the Devil', Film Comment, 34, 5, September/ October: 20

Kalin, T. (1998) 'Forced perspective', Filmmaker, 7, 1: 60-62, 65

Kris, E. and Kurz, O. (1979) Legend, Myth, and Magic in the Image of the Artist: A Historical Experiment, New Haven: Yale University Press

Lagose, A. (1966) Queer Theory, Carlton South, Victoria: University of Melbourne Press. (Interpretations)

Lent, T. O. (2007) 'Life as art/ art as life', Journal of Popular Film and Television, 35, 2, Summer: 68-76

Lucie-Smith, E. (1979) 'The gay seventies?', Art and Artists, 14, 8, December: 4-11

Macnab, G. (1997) 'Bohemian rhapsody', Sight and Sound, 7, 7, July: 18-20

Maybury, J. (1998) Love is the Devil: [Shooting Script], Unpublished: BFI Script Collection S20375

Monk, C. (2000) 'Men in the 1990s British cinema' In: Murphy, R., British Cinema of the 90s, London: BFI pp.156-166

Peake, T. (1991) Derek Jarman, London: Little, Brown and Company

Rich, B. R. (1992) 'New queer cinema', Sight and Sound, 2, 5, September: 30-35

Rich, B R. (2000) 'Queer and present danger', Sight and Sound, 10, 3, March:22-25

Richards, J. (1997) Films and British National Identity: From Dickens to Dad's Army, Manchester: Manchester University Press. (Studies in Popular Culture)

Richardson, N. (2005) 'Queering a gay cliché: the rough trade/sugar daddy relationship in Derek Jarman's "Caravaggio"', Paragraph, 28, 3, November: 36-53

Richmond, L. (1975) 'Breaking up is hard to do', Time Out, 263, 14 March: 7

Ryman, G. (1975) 'When love goes wrong', Quorum, 3, 3/4, May: 10-14

Simpson, M. (1994) Male Impersonators, London: Cassell 
Sinfield, A. (1998) Gay and After, London: Serpent's Tail

Spitz, M. (2010) David Bowie: A Biography, London: Aurum

Stacey, J. and Street, S. (2007) 'Introduction: queering "Screen"', In, Stacey, J. and Street, S. eds. Queer Screen: A "Screen" Reader, London: Routledge pp.1-18

Vachon, C. (1998) Shooting to Kill: How an Independent Producer Blasts Through the Barriers to Make Movies that Matter, London: Bloomsbury

Walker, A. (1997) 'Screen images', National Art Collection Fund Quarterly, Autumn: 50-53

Webb, P. (1988) Portrait of David Hockney. London: Chatto \& Windus

Weston, A. (1998) 'Love is the Devil', Evening Standard, 8 May: 19

Willis, H. (1998) 'Brush with the gutter', American Cinematographer, 79, 9, September: 46-55

Wittkower, R. and Wittkower, M. (2007) Born under Saturn, New York: New York Review. (New York Review Books Classics). Originally published 1963

Wojnarowicz, D. (1992) Close to the Knives: a Memoir of Disintegration, London: Serpent's Tail

Wymer, R. (2005) Derek Jarman, Manchester: Manchester University Press

\footnotetext{
${ }^{\mathrm{i}}$ The historical development of such interpretations is given in Kris (1979) and Wittkower (2007). The pervasiveness of the tropes within a particular film, for example, Frida (Julie Taymor, 2002), about Frida Kahlo, is analysed in Lent (2007: 70-71).

${ }^{\text {ii }}$ I believe the conclusions apply equally to the wider boundaries of a queer sexuality, manifested in other artist biopics such as Frida (Julie Taymor, 2002) or the fictional Boogie Woogie (Duncan Ward, 2009). A biography of artist Lili Elbe (born Einer Wegener), who received the world's first gender reassignment surgery, was announced in 2009, with Nicole Kidman both producing and starring. It was put on hold in 2011 (Anderson-Minshall, 2011). Derek Jarman, the English film director, who will feature prominently in this article, always preferred the term queer. He said, "I was never gay, queer maybe, difficult certainly, with good reason" (quoted in Wymar, 2005: 3).

iii Dyer (1993: 75) takes such discussion beyond the cinema for the gay component of a queer image. He sees the stereotype of the image of the homosexual as a sad young man, made sad by the short-term nature of the majority of gay relationships, a lack of children and a fierce social opprobrium, as being visible across the gay literature of the UK and the USA from the 1940s to 1960s, in plays, dance, song and in both high and low culture.

${ }^{\text {iv }}$ The film gained cult status and was so popular it warranted a sequel, The Hitcher 2: I've Been Waiting (Louis Morneau, 2003), which went straight to video, and also a remake, The Hitcher (Dave Myers, 2007) with Sean Bean replacing Rutger Hauer as the murderous passenger.

" Simpson (1994: 154) defines a 'hustler' as "a straight boy living by offering his body to gay men, taking this as affirmation of his heterosexuality".

${ }^{\text {vi }}$ The sounds were recorded in Pitiliano (Jarman, 1986: 94).
} 
vii Caravaggio says, "I built the world as Divine Mystery and found the god in the wine, and took him to my heart. I painted myself as Bacchus and took on his fate, a wild orgiastic dismemberment. I raise this fragile glass and drink to you, my audience. Man's character is his fate" (Jarman, 1986: 27).

${ }^{\text {viii }}$ The mood also owes much to the casting of Dexter Fletcher as the young Caravaggio, playing the street-wise cockney, which was to become his stock-in-trade. Fletcher was already a little too old for this part, but Jarman was probably protecting himself from censorship battles in the same way he used Dawn Archibald's gymnastic female angel rather than a naked boy to evoke Caravaggio's painting of Cupid, Amor Vincit Omnia (Jarman, 1986: 75).

${ }^{\text {ix }}$ Macnab (1997: 20) has noted that "up until recently, there was a strange camaraderie between the upper classes and lower classes which excluded the middle classes, certainly in homosexual culture". The prominence of this sub-cultural myth within gay literature is summarised in Sinfield (1998: 95-99). ${ }^{x}$ As Jarman (1984: 22) has described in one of his published diaries, "Michelle [i.e. Caravaggio] gazes wistfully at the hero slaying the saint [with Thomasoni modelling the role]. It is a look no one can understand unless he has stood till 5.00 am in a gay bar hoping to be fucked by that hero. The gaze of the passive homosexual at the object of his desire, he waits to be chosen, he cannot make the choice". ${ }^{\mathrm{xi}}$ While I will be arguing that a discussion of a queer lifestyle is generally quite open in the artist biopic, the older, more discreet, attitudes do live on. For example, in Caravaggio (2007), which was envisaged as a 200 minute television production for potential family audiences, as well as a 130 minute theatrical version, there are only veiled references to the painter's bisexuality. When a painting of Bacchus modelled by Caravaggio's closest 'friend' Mario Mimiti lies next to Caravaggio's hospital bed, a wounded soldier, Onorio Longhhi, in the next bed asks "Who's that lady?" Caravaggio replies "A friend" and Onorio sums up the unspoken implications with "Better a pederast than a Spaniard". Again, in Dali (1991) the matter of Dalí's relationship with Federico Lorca is raised only once for it to be quickly dismissed. The script paraphrases a quote from an interview with Alain Bosquet (1969: 1920), with Dalí saying in voiceover, "When Lorca tried to seduce me, I was repulsed. I'm not a homosexual. The fact that the greatest Spanish poet desired my divine arse wasn't that bad. Anyone would have liked it".

xii Although generally supportive of Maybury, the BBC did insist on censoring one minute from the film. A fourteen year old actor, playing the teenage Bacon, appeared to be involved in a sex scene in his father's stables. This removed the only reference in the film to Bacon's life outside the years of his relationship with George Dyer ('Bacon sliced', 1997: 1).

xiii Scotland followed in 1980 and Northern Ireland in 1982. Legislation did not cover members of the Merchant Navy or Armed Forces. The age of consent was gradually reduced, to 18 in 1994 and 16 in 2000, thus putting it on a par with heterosexual behaviours. Civil Partnerships were granted under the Civil Partnership Act 2004, giving same-sex couples rights and responsibilities identical to civil marriage (Cook, 2007: 185, 211-212).

${ }^{x i v}$ For examples of Walker's articles see the London Evening Standard, on 08/05/1998, Page 19, 'Beef cake but no Bacon'; 14/05/1998, Page 47, 'The Devil of a misdirection; 17/05/1998, Page 22, 'Blank portrait of an artist'. The latter included a description of the film as “John Maybury's porno-biography of Francis Bacon" and he castigates both the Arts Council and the BBC because "Both bodies have a cultural and educational remit that takes priority: they should not be patrons in a porn show". (The articles are included in the BFI Press Cuttings Microfiche Collection).

${ }^{x v}$ The homophobic abuse Warhol was subjected to outside the art world is very effectively conveyed by the calculated brutal verbal attack on him mounted by the father of his 'superstar' Edie Sedgwick in Factory Girl. Edie proudly takes him to meet her parents for the first time at a top New York restaurant. In this very public arena her father says very loudly, "Who is this guy who has my little girl turned around? He must be some kind of man. Then I talk to you for two minutes, and I have to smile because I don't have a thing to worry about, do I? You're a full-blown queer."

${ }^{x v i}$ This was by no means deliberate, just happy circumstance. The producers of I Shot Andy Warhol recognised that they had been caught out over the making of Basquiat at roughly the same time. Basquiat, with its much higher profile cast and the backing of Miramax as distributor, completely overshadowed the Valerie Solanus vehicle (Vachon, 1998: 279).

${ }^{x v i i}$ The black leather jacket Bowie wears in the film belonged to Warhol. Bowie was in addition given access to handle many of Warhol's personal belongings held by the Warhol Museum in Pittsburgh. Bowie was most affected by handling the small handbag Warhol took with him into hospital, containing a number of personal mementoes (Spitz, 2010: 364). 